\title{
Use of high doses of 18:0 to try to mitigate the syndrome of milk fat depression in dairy ewes fed marine lipids
}

\author{
Pablo G. Toral*, Gonzalo Hervás and Pilar Frutos \\ Instituto de Ganadería de Montaña (CSIC-Universidad de León), Finca Marzanas s/n,
} 24346 Grulleros, León, Spain

*Corresponding author. E-mail address: pablo.toral@csic.es

\begin{abstract}
Despite the benefits of adding marine lipids rich in $n-3$ polyunsaturated fatty acids (PUFA) to ruminant diets to improve milk fatty acid (FA) composition, this strategy induces milk fat depression (MFD), precluding its application under practical conditions. The MFD elicited by marine lipids has tentatively been explained by a shortage of available ruminal 18:0 for mammary uptake and $\Delta^{9}$-desaturation to cis-9 $18: 1$, which might increase milk fat melting point and impair fat secretion. This hypothesis was challenged in a recent experiment in dairy ewes, as diet supplementation with $2 \%$ DM of 18:0 did not prove useful to alleviate fish oil-induced MFD. However, further research with higher levels of 18:0 inclusion seemed advisable. Therefore, in this study, 16 lactating ewes were allocated to 4 treatments lasting 27 days: a total mixed ration containing no additional lipid (control) or 2\% DM of fish oil alone (FO) or in combination with $3 \%$ (FOSA3) or 4\% (FOSA4) of stearic acid. Fish oil supplementation induced MFD, but addition of 18:0, regardless of the dose, was not able to mitigate it: decreases in milk fat content reached 19\% in FO, 20\% in FOSA3 and 27\% in FOSA4. The reduction
\end{abstract}


in milk 18:0 concentration due to FO $(-81 \%)$ was completely reverted neither by FOSA3 $(-41 \%)$ nor by FOSA4 (-25\%), and something similar occurred with cis-9 18:1 concentrations $(12.53,5.91,9.50$ and $11.28 \mathrm{~g} / 100 \mathrm{FA}$, in control, FO, FOSA3 and FOSA4, respectively). Increases in some candidate milk fat inhibitors in FO and FOSA diets (e.g., cis-9 16:1, cis-11 18:1, trans-10 18:1, 10-oxo-18:0, or trans-10 cis-15 18:2) might account for the absence of a positive effect of dietary 18:0. The estimated milk fat melting point was lower in the three supplemented diets (on average, $-2.6^{\circ} \mathrm{C}$ compared with the control). In conclusion, addition of high doses of stearic acid to the diet (at 3 and 4\% DM) was not able to alleviate the MFD caused by the concomitant supplementation with fish oil. This lack of response would further challenge the hypothesis suggesting that fish oil-induced MFD is mainly explained by decreased ruminal production of 18:0 and subsequent problems of milk fat fluidity, but further research would be still needed.

Key words: fish oil; low-fat milk syndrome; ruminant nutrition; sheep; stearic acid

Abbreviations: ADF, acid detergent fibre; aNDF, neutral detergent fibre; $\mathrm{BH}$, biohydrogenation; CLA, conjugated linoleic acid; DM, dry matter; FA, fatty acid; FAME, fatty acid methyl ester; FO, fish oil; MFD, milk fat depression; MMP, milk fat melting point; PUFA, polyunsaturated fatty acid; SA, stearic acid; TMR, total mixed ration. 


\section{Introduction}

Supplementation of dairy ewe diets with marine lipids rich in n-3 polyunsaturated fatty acids (PUFA) is known to be able to modulate milk fatty acid (FA) composition towards a potentially healthier profile for consumers [e.g., with a higher proportion of trans-11 18:1, cis-9 trans-11 conjugated linoleic acid (CLA) and very long-chain n-3 PUFA; Reynolds et al., 2006; Toral et al., 2010; Tsiplakou and Zervas, 2013]. The low levels that are required (usually, $\leq 2 \%$ diet DM) would have no negative effects on shelflife and sensory properties of dairy products (e.g., Jones et al., 2005).

However, besides beneficial effects, this feeding strategy causes milk fat depression (MFD; Rego et al., 2005; Bichi et al., 2013; Carreño et al., 2016), which precludes its use under practical conditions, particularly in sheep and goat farms where most milk is used for the manufacture of cheeses (Chilliard et al., 2006; Ramos and Juárez, 2011).

Several hypotheses or theories explaining the origin of MFD have been proposed and subsequently found inadequate or incomplete (Bauman and Griinari, 2001; Shingfield and Griinari, 2007). The Biohydrogenation (BH) theory proposed by Bauman and Griinari in 2001 establishes that MFD relates to an inhibition of mammary lipogenesis by specific $\mathrm{BH}$ intermediates that are produced under certain feeding conditions that alter rumen function. This is the most widely accepted theory. Another hypothesis, trying to explain more specifically the marine lipid-induced MFD, is based on the shortage of 18:0 (caused by the inhibitory action of marine lipids on the last step of rumen BH; Loor et al., 2005; Shingfield and Griinari, 2007) for cis-9 18:1 synthesis in the mammary gland. Since this latter FA has a low melting point, its scarcity would exert a negative impact on the maintenance of milk fat melting point (MMP) below body temperature (Timmen and Patton, 1988; Bernard et al., 2013) and, consequently, on milk fat fluidity and secretion, causing the low-fat milk syndrome (Chilliard et al., 2007; Shingfield and Griinari, 2007). 
Nevertheless, in a previous dedicated study with lactating ewes (Toral et al., 2016), we observed the same reduction in milk fat concentration and yield $(20 \%)$ in sheep supplemented with fish oil ( $2 \% \mathrm{DM})$ alone or in combination with stearic acid (SA, $2 \%$ DM). The lack of effect of dietary SA challenged the premise of a shortage of this FA to explain fish oil-induced MFD in dairy ewes. However, before ruling out a mechanism based on decreased ruminal production of 18:0 and subsequent alterations of milk fat fluidity, we decided to conduct a new assay with higher doses of SA (i.e., 3 and 4\% DM).

\section{Material and methods}

All experimental procedures were approved and completed in accordance with Spanish and EU legislations (R.D. 53/2013, and Council Directive 2010/63/EU) for the protection of animals used for experimental purposes.

\subsection{Animals, experimental diets and management}

Sixteen lactating Assaf ewes $(79.0 \pm 2.94 \mathrm{~kg}$ of body weight; $83.4 \pm 2.65$ days in milk at the beginning of the assay) were housed in tie stalls and allocated to one of 4 groups $(n=4)$. Dietary treatments were comprised of alfalfa hay and a concentrate $(40: 60)$ and contained no additional lipid (control) or 2\% DM of fish oil (Afampes 121 DHA; Afamsa, Mos, Spain) alone (FO) or in combination with 3\% (FOSA3) or 4\% (FOSA4) DM of SA (prilled free FA supplement; Edenor C18 98-100; Oleo Solutions, York, UK). The ingredients and chemical composition of the experimental diets, which were prepared weekly, are shown in Table 1. To try to reduce selection of components, diets included molasses and were offered as total mixed rations (TMR). All sheep were fed the control TMR during 3 weeks of adaptation before the start of the study, and then the 4 experimental treatments for 27 more days. The diets were offered ad libitum twice daily, 
at 09:30 and 18:30 h, and clean drinking water was always available. Ewes were milked at approx. 09:00 and 18:00 h in a $1 \times 10$ stall-milking parlor (DeLaval, Madrid, Spain).

\subsection{Measurements and sampling procedures}

Representative samples of the experimental diets, collected weekly, and the fish oil and stearic acid were stored at $-30^{\circ} \mathrm{C}$ until analysis. Feed intake was recorded each week by weighing the amount of DM offered and refused by each lot of 4 sheep.

Milk yield was recorded on days 25, 26 and 27 on the experimental diets. Individual milk samples were collected and composited according to morning and evening milk yield. One $10-\mathrm{mL}$ aliquot of composite milk was stored at $-30^{\circ} \mathrm{C}$ until milk FA composition analysis; another aliquot of $50 \mathrm{~mL}$ was preserved with bronopol (D \& F Control Systems Inc., San Ramon, CA, USA) and stored at $4^{\circ} \mathrm{C}$ until analyzed for fat, protein, lactose and total solids.

\subsection{Chemical analysis}

\subsubsection{Diets}

Samples were analyzed for DM (ISO 6496:1999), ash (ISO 5984:2002), and crude protein (ISO 5983-2:2009). The neutral and acid detergent fibres (aNDF and ADF) were determined using an Ankom ${ }^{2000}$ fiber analyzer (Ankom Technology Methods 13 and 12, respectively; Ankom Technology Corp., Macedon, NY, USA); the former was assayed with sodium sulfite and $\alpha$-amylase, and both were expressed with residual ash. Fatty acid methyl esters of lipid in freeze-dried samples of TMR were prepared in a 1-step extraction-transesterification procedure using chloroform and $2 \%(\mathrm{vol} / \mathrm{vol})$ sulfuric acid in methanol (Shingfield et al., 2003), and cis-12 tridecenoate (Larodan, Solna, Sweden) as an internal standard. Methyl esters were separated and quantified using a gas 
chromatograph (Agilent 7890A GC System, Agilent Technologies Inc., Santa Clara, CA, USA) equipped with a flame-ionization detector and a 100-m fused silica capillary column (0.25 mm i.d., 0.2- $\mu \mathrm{m}$ film thickness; CP-SIL 88, CP7489, Varian Ibérica S.A., Madrid, Spain) and hydrogen as the carrier gas $(207 \mathrm{kPa}, 2.1 \mathrm{~mL} / \mathrm{min})$. The total FAME profile in a $2-\mu \mathrm{L}$ sample volume at a split ratio of 1:50 was determined using a temperature gradient program (Shingfield et al., 2003). Peaks were identified based on retention time comparisons with commercially available standard FAME mixtures $(\mathrm{Nu}-$ Chek Prep., Elysian, MN, USA; and Sigma-Aldrich, Madrid, Spain).

\subsubsection{Milk}

Fat, protein, lactose and total solid concentrations were determined by infrared spectrophotometry (ISO 9622:1999) using a MilkoScan FT6000 (Foss, Hillerød, Denmark). Lipid in $1 \mathrm{~mL}$ of milk was extracted using diethylether and hexane (5:4, $\mathrm{vol} / \mathrm{vol}$ ) and transesterified to fatty acid methyl ester (FAME) using freshly prepared methanolic sodium methoxide as a catalyst (Shingfield et al., 2003). The total FAME profile was determined by gas chromatography using the same chromatograph and temperature gradient program applied for the analysis of feeds, but isomers of 18:1 were further resolved in a separate analysis under isothermal conditions at $170^{\circ} \mathrm{C}$ (Shingfield et al., 2003). Peaks were identified based on retention time comparisons with the same FAME mixtures used for the analysis of feeds, other commercially available standards (Nu-Chek Prep.; Sigma-Aldrich; and Larodan), cross referencing with chromatograms reported in the literature (Shingfield et al., 2003; Halmemies-Beauchet-Filleau et al., 2011), and comparison with reference samples for which the FA composition was determined based on gas chromatography analysis of FAME and GC-MS analysis of corresponding 4,4-dimethyloxazoline derivatives (Bichi et al., 2013). 


\subsection{Calculations and statistical analysis}

The mean MMP was estimated as the sum of the melting points of individual FA (95 in total) weighted by their respective molar proportions (Toral et al., 2013).

All statistical analyses were performed using the SAS software package (version 9.4; SAS Institute Inc., Cary, NC, USA). Data of animal performance and milk FA composition were analyzed by one-way ANOVA with a model that included the fixed effect of treatments (control, FO, FOSA3 and FOSA4; mean values over days 25, 26 and 27) and the animals nested within treatments. Three preplanned orthogonal contrasts were used to examine 1) the effects of dietary addition of fish oil: Control vs. FO-diets (i.e., FO, FOSA3 and FOSA4), or 2) stearic acid: FO vs. FOSA-diets (i.e., FOSA3 and FOSA4), and 3) differences between the two FOSA treatments: FOSA3 vs. FOSA4. Differences were declared significant at $P<0.05$ and considered a trend towards significance at $P<0.10$. Least squares means are reported.

\section{Results}

\subsection{Animal performance}

Data of animal performance are shown in Table 2. According to the experimental design, addition of fish oil to the diet caused MFD, which was characterized by a significant lower milk fat concentration in ewes consuming this supplement (i.e., FO, FOSA3 and FOSA4) compared to those on the control $(\mathrm{P}<0.01)$. Fat production $(\mathrm{g} /$ day $)$ was not significantly reduced due to the numerically (although not statistically significant; $\mathrm{P}>0.10$ ) higher milk production in these supplemented animals. Within them (i.e., in ewes fed the FO, FOSA3 and FOSA4 diets) similar milk yields were observed (P $>0.10)$. The lower fat concentrations were reflected in lower contents of total solids in 
ewes on the three treatments containing fish oil $(\mathrm{P}<0.05)$, without significant variations between FO- and FOSA-diets, or between FOSA3 and FOSA4 $(\mathrm{P}>0.10)$. No variations were detected in protein or lactose either $(\mathrm{P}>0.10)$.

Values of DMI were similar for the 4 treatments and remained relatively stable throughout the trial (on average, $3.33 \pm 0.06,3.28 \pm 0.11,3.07 \pm 0.16$ and $3.31 \pm 0.05 \mathrm{~kg}$ DM/day for control, FO, FOSA3 and FOSA4). They were not statistically analysed and included in Table 2 because they were recorded for the lot and not individually.

\subsection{Milk fatty acid composition}

As shown in Table 3, all diets supplemented with fish oil modified the proportion of several individual short and medium-chain FA but, as a whole, only the addition of SA (FOSA3 and FOSA4) reduced the concentration of $<$ C16 and C16 FA $(\mathrm{P}<0.05)$. On the contrary, FOSA-diets increased the proportion of $>\mathrm{C} 16$ FA: the higher the dose of SA, the greater the concentration of $>$ C16 FA $(\mathrm{P}<0.05)$.

The sum of saturated FA was decreased by FO-diets $(\mathrm{P}<0.001)$, the strongest effects being observed with FOSA3 and FOSA4 $(\mathrm{P}<0.001)$ but without significant differences between them ( $\mathrm{P}>0.10$ for FOSA3 vs. FOSA4). This reduction was largely due to the lower concentration of 18:0 in the milk from sheep on the diet supplemented with fish oil alone (FO; $1.36 \%)$ compared with the control $(7.18 \%)$, as well as in FOSA3 (4.23\%) and FOSA4 (5.42\%), with significant differences between the two latter $(\mathrm{P}<$ 0.05). Decreases in 10:0, 12:0 and 16:0 concentrations after SA addition would contribute to explain the differences in total saturates between FO and FOSA treatments $(\mathrm{P}<0.05)$. Some significant increases in individual saturated FA in response to fish oil were also observed (e.g., in 6:0, 8:0 and 10-oxo-18:0).

In general, the addition of SA, regardless of the dose, caused little changes in odd- 
and branched-chain FA and in 16:1 isomers that had already being altered by FO (e.g., cis-9 16:1; $\mathrm{P}<0.001)$.

Concentrations of most trans-18:1 isomers were increased by all FO-diets $(\mathrm{P}<$ 0.05), with differences between FO and FOSA3+FOSA4 in some cases. For instance, this was particularly clear for trans-10 18:1 ( $\mathrm{P}<0.10)$, which showed values reaching up to 13-fold increases when animals received dietary SA, and for trans-11 18:1 $(\mathrm{P}<0.05)$.

Isomers of $c i s-18: 1$ were also significantly affected by consumption of fish oil or SA. As expected, most remarkable changes occurred in cis-9 18:1, with a strong reduction when fish oil alone was provided (5.91 in FO vs. $12.53 \%$ in control) that was partially reverted in FOSA3 (9.50\%) and FOSA4 (11.28\%). Differences were detected not only between FO- and FOSA-diets $(\mathrm{P}<0.001)$ but also between the two latter (i.e., FOSA3 and FOSA4). Decreases in milk cis-9 18:1 and 18:0 were not equivalent, which resulted in an increment in the $\Delta^{9}$-desaturation index based on the cis-9 18:1/(cis-9 18:1 + 18:0) ratio that was particularly high in $\mathrm{FO}(0.813 \pm 0.0050)$, compared with the control $(0.636$ $\pm 0.0467)$ and FOSA diets (on average, $0.684 \pm 0.0071$ ).

The positive effect of fish oil supplementation on the concentration of total CLA was limited by the addition of SA to the diet. This was evident, for example, in the cis-9 trans-11 CLA isomer, which was strongly increased by FO alone and to a lower extent by FOSA3 and FOSA4 $(\mathrm{P}<0.05)$. On the other hand, the proportion of trans-10 cis-12 CLA was only favoured by dietary SA $(\mathrm{P}<0.05)$. Diet-induced variations in other 18 carbon PUFA (e.g., 18:2n-6 or 18:3n-3) were in general less pronounced and attributed to the action of fish oil.

Something similar occurred with C20 and C22 FA. Changes observed in these FA, particularly the enhancement of very long chain PUFA (e.g., eicosapentaenoic acid, 20:5n-3; docosapentaenoic acid, 22:5n-3; and docosahexaenoic acid, 22:6n-3), were 
mostly due to fish oil supplementation ( $\mathrm{P}<0.001)$. Only milk concentrations of 20:0 and 22:6n-3 showed higher values with the addition of $\mathrm{SA}(\mathrm{P}<0.01$ and 0.10 , respectively).

Concerning the estimated melting point, milk fat from control ewes showed higher values than that from animals fed fish oil-containing diets (i.e., FO, FOSA3 and FOSA4; $\mathrm{P}<0.001$ ), but without significant differences among the latter.

\section{Discussion}

Supplementation with fish oil (i.e., FO, FOSA3 and FOSA4 diets) modulated milk FA composition towards a profile potentially healthier for the consumer (Palmquist et al., 2005; Chilliard et al., 2007). Since a number of experiments, including some conducted by our team (e.g., Toral et al., 2010; Bichi et al., 2013), have examined this effect of marine lipids in dairy ewes (Reynolds et al., 2006; Capper et al., 2007; Tsiplakou and Zervas, 2013) and this is not the objective of the present study, this part will only be mentioned briefly. Thus, dietary addition of fish oil increased, for instance, the concentration of cis-9 trans-11 CLA, its precursor trans-11 18:1, very long chain n-3 FA (e.g., 20:5n-3, 22:5n-3 and 22:6n-3) or total PUFA. These changes agree with previous reports under similar conditions (e.g., Tsiplakou and Zervas, 2013; Toral et al., 2015).

At the same time, as designed and expected (Capper et al., 2007; Carreño et al., 2016; Toral et al., 2016), diet supplementation with fish oil (namely, the FO treatment) caused MFD, which was characterized by a significant lower milk fat concentration compared to that of the control. The lack of impact on milk fat production might be partly attributed to the numerical but not significant increase in milk yield. Given the high individual variation observed in this experiment for that parameter (milk yield), statistical power limitations related to the low number of animals cannot be ruled out. Nevertheless, in a previous assay in which milk yield was greater in ewes consuming fish oil (Suárez- 
Vega et al., 2017), a comprehensive analysis of mammary transcriptome suggested that the lower milk fat percentage was not just a dilution effect but a response to the downregulation of genes involved in mammary lipogenesis.

Decreases in milk fat concentrations were similar in ewes fed the FO, FOSA3 and FOSA4 diets $(\mathrm{P}>0.10)$, showing that addition of SA, regardless of the dose, was not able to reverse the negative effect of fish oil. In fact, when compared with the control, decreases in milk fat concentration reached $19 \%$ in FO, $20 \%$ in FOSA3 and $27 \%$ in FOSA4. These drops are within the range usually reported in dairy ewes suffering marine lipid-induced MFD (from -17 to $-31 \%$ decrease; Toral et al., 2010, 2015; Bichi et al., 2013) and agree with those observed in the previous trial conducted with FO and $2 \%$ SA $(-20 \%$; Toral et al., 2016), which would support that the lack of effect of SA supplementation was not due to the dose.

The fish oil-induced MFD has been linked to a shortage of available 18:0, caused by the inhibition of the last step of ruminal $\mathrm{BH}$ and, consequently, a lower mammary endogenous synthesis of cis-9 18:1 (Loor et al., 2005; Shingfield and Griinari, 2007; Gama et al., 2008). The increase in the milk cis-9 18:1/(cis-9 18:1+18:0) concentration ratio with FO might be interpreted as an indication of compensatory mechanisms for the oleic acid deficit, but we are not aware of reports measuring in vivo SCD enzyme activity under similar MFD conditions. In this respect, between 48 and 57\% of milk cis-9 18:1 has been estimated to derive from 18:0 $\Delta^{9}$-desaturation in the mammary gland of dairy ewes fed a similar basal diet to that used in the present trial (Frutos et al., 2014; Toral et al., 2017). In dairy cows consuming conserved forages and concentrates, estimations of endogenous milk cis-9 18:1 synthesis also range from approx. 48 to 64\% (Griinari et al., 2000; Leskinen et al., 2016). This FA has a low melting point $\left(16.0^{\circ} \mathrm{C}\right)$ and it is therefore considered to play a key role in maintaining milk fat melting point below body 
temperature and ensuring milk fat fluidity and secretion (Timmen and Patton, 1988; Shingfield and Griinari, 2007; Bernard et al., 2013). In this assay, the deep decrease in 18:0 due to FO $(-81 \%)$ was completely reverted neither by FOSA3 $(-41 \%)$ nor by FOSA4 $(-25 \%)$. Conversely, the concentration of cis-9 18:1 fell less severely with FO (-53\%) and values in FOSA3 and FOSA4 (9.50 and $11.28 \mathrm{~g} / 100 \mathrm{~g} \mathrm{FA}$, respectively) were closer to that of the control $(12.53 \%)$. These changes are in line with those reported previously in Toral et al. (2016) and would also support that the lack of response to dietary SA supplementation, in terms of MFD severity, was not related to its dose (2, 3 or $4 \%$ DM).

In any event, decreases in 18:0 and cis-9 18:1 do not seem to be actually responsible for impaired milk fat fluidity due to inadequate melting point. In fact, estimated MMP was lower in animals receiving the three FO supplemented diets, which seems to contradict the milk fat fluidity hypothesis and some previous findings in ruminants fed marine lipids (Gama et al., 2008; Toral et al., 2010), although it agrees with some others (Toral et al., 2013, 2016; Kairenius et al., 2015). These inconsistences might be, at least in part, accounted for by counteracting effects on a number of individual FA, including some that would be relevant to affect MMP in one direction or another. For example, increases in some short-chain FA, some CLA isomers or 20:5n-3, 22:5n-3 and 22:6n-3, with very low melting points, and decreases in some others, such as 12:0 or 16:0, with high melting points (LipidBank Database, http://www.lipidbank.jp).

Nevertheless, mechanisms linked to milk fat fluidity cannot be completely ruled out because this study, as well as most others, was conducted on milk fat that was successfully secreted, but triacylglycerols with high melting point might accumulate in mammary epithelial cells and inhibit lipogenesis (Gama et al., 2008; Toral et al., 2016). Further research would be then needed before being able to firmly demonstrate or reject the hypothesis of milk fat fluidity. 
Diet supplements enriched with individual FA (particularly, palmitic acid and stearic acid) are becoming progressively more available and used to enhance milk and milk fat yield (Loften et al., 2014; Boerman et al., 2017). However, the main aim of using SA in this study was not to improve dairy sheep performance directly but indirectly through mitigation of fish oil detrimental effects.

The reasons underlying the lack of response to dietary SA in the present and in our previous trial (Toral et al., 2016) are still uncertain but may be related to dose-dependent side effects of feeding this saturated FA. A recent work by Boerman et al. (2017) has proved that although 18:0 is the main end product of $\mathrm{BH}$, it is not so inert as often considered. Thus, they found that increasing doses of dietary SA caused a marked decrease in 18-carbon FA digestibility (up to approx. $-30 \%$ with $2.30 \%$ of a free FA product containing 93\% 18:0, very similar to our supplement). Alterations of rumen lipid metabolism, which are suggested, for example, by large increments in milk trans-10 18:1, in trans-6+7, trans-8 and trans-9 16:1, or in 10-oxo-18:0, and poor mammary uptake might also be behind the absence of effects (Enjalbert et al., 1998; Toral et al., 2016).

As previously suspected (Leskinen et al., 2016; Toral et al., 2016), results would point again to the $\mathrm{BH}$ theory, with a significant contribution of some FA produced under altered ruminal conditions (Bauman and Griinari, 2001; Shingfield and Griinari, 2007). Thus, some potentially antilipogenic FA, such as trans-10 18:1, trans-9 cis-11 and trans10 cis-12 CLA, were favoured in the 3 diets inducing MFD. Interestingly, increases were stronger (e.g., in trans-10 18:1) or even only significant (e.g., in trans-10 cis-12 CLA) in FOSA3 and FOSA4 treatments, which may contribute to explain why the addition of 18:0 to the TMR was not able to mitigate the low-fat milk syndrome. The basal diet composition (with a high concentrate level) may also affect the extent of these rumen $\mathrm{BH}$ responses to lipid supplements (Chilliard et al., 2007; Shingfield and Griinari, 2007). 
Quite recently, some studies (e.g., Alves and Bessa, 2014; Kairenius et al., 2015; Toral et al., 2015) have suggested the contribution to MFD of less well-known antilipogenic FA. The inhibitory action of most of these candidate FA is only tentative yet (Kadegowda et al., 2009; Burns et al., 2012) and should be proven in further studies. Examples of such bioactive compounds are FA promoted under altered rumen function, such as intermediates of minor 18:3n-3 biohydrogenation pathways (e.g., trans-10 cis-15 18:2, which in our chromatographic conditions coeluted with trans-11 cis-15 18:2). Other putative milk fat inhibitors include certain FA supplied with fish oil (e.g., cis-9 16:1, cis11 18:1 and very long-chain n-3 PUFA) that might account for the reductions in milk fat synthesis after post-ruminal infusions of this marine lipid (Loor et al., 2005; Dallaire et al., 2014). As shown in Table 3, all these FA were similarly increased with FO and FOSA treatments, which would contribute as well to explain the lack of effect of dietary SA.

Increases with fish oil in keto-FA, namely 10-oxo-18:0, which results from the sequential hydration and oxidation of unsaturated FA in the rumen (Jenkins et al., 2006) have also been observed in sheep and cows during fish oil-induced MFD (Bichi et al., 2013; Kairenius et al., 2015; Toral et al., 2016). Although some oxylipids may have biological activity in ruminants (e.g., Raphael et al., 2014), we are not aware of published studies about the effects of keto-FA on mammary lipogenesis. However, changes in these FA deriving from alternative pathways to $\mathrm{BH}$ might suggest that more global changes in the ruminal lipid metabolism may be involved in eliciting MFD (Shingfield and Griinari, 2007). In line with potential antilipogenic FA mentioned above, increases in 10-oxo-18:0 were also similar in FO- and FOSA-treatments.

In conclusion, addition of high doses of stearic acid to the diet of lactating ewes (3 and $4 \% \mathrm{DM}$ ) was not able to alleviate the milk fat depression caused by the concomitant supplementation with fish oil (2\% DM). In fact, the higher the dose of SA, the worse the 
results. This lack of response would further challenge the hypothesis suggesting that fish oil-induced MFD is mainly explained by decreased ruminal production of 18:0 and subsequent problems of milk fat fluidity, but further research would be still needed.

Conflicts of interest: None.

\section{Acknowledgements}

This work was supported by the Council of Castile and Leon (CSI023U13). The authors thank D. Carreño, A. G. Mendoza and L. Rodríguez for their help with experimental animals and fatty acid analysis. Pablo Toral benefits from a Ramón y Cajal research contract from the Spanish Ministry of Economy, Industry and Competitiveness (RYC-2015-17230), co-funded by the European Regional Development Fund.

\section{References}

Alves, S., Bessa, R.B., 2014. The trans-10,cis-15 18:2: a missing intermediate of trans10 shifted rumen biohydrogenation pathway? Lipids 49, 527-541.

Bauman, D.E., Griinari, J.M., 2001. Regulation and nutritional manipulation of milk fat: low-fat milk syndrome. Livest. Prod. Sci. 70, 15-29.

Bernard, L., Leroux, C., Chilliard, Y., 2013. Expression and nutritional regulation of stearoyl-CoA desaturase genes in the ruminant mammary gland: Relationship with milk fatty acid composition, in: Ntambi, J.M. (Ed.), Stearoyl-CoA desaturase genes in lipid metabolism. Springer Science+Business, New York, NY, USA, pp. 161-194.

Bichi, E., Hervás, G., Toral, P.G., Loor, J.J., Frutos, P., 2013. Milk fat depression induced by dietary marine algae in dairy ewes: Persistency of milk fatty acid composition and animal performance responses. J. Dairy Sci. 96, 524-532. 
Boerman, J.P., de Souza, J., Lock, A.L., 2017. Milk production and nutrient digestibility responses to increasing levels of stearic acid supplementation of dairy cows. J. Dairy Sci. 100, 2729-2738.

Burns, T.A., Kadegowda, A.K.G., Duckett, S.K., Pratt, S.L., Jenkins, T.C., 2012. Palmitoleic (16:1 cis-9) and cis-vaccenic (18:1 cis-11) acid alter lipogenesis in bovine adipocyte cultures. Lipids 47, 1143-1153.

Capper, J.L., Wilkinson, R.G., Mackenzie, A.M., Sinclair, L.A., 2007. The effect of fish oil supplementation of pregnant and lactating ewes on milk production and lamb performance. Animal 1, 889-898.

Carreño, D., Hervás, G., Toral, P.G., Castro-Carrera, T., Frutos, P., 2016. Fish oil-induced milk fat depression and associated downregulation of mammary lipogenic genes in dairy ewes. J. Dairy Sci. 99, 7971-7981.

Chilliard, Y., Glasser, F., Ferlay, A., Bernard, L., Rouel, J., Doreau, M., 2007. Diet, rumen biohydrogenation and nutritional quality of cow and goat milk fat. Eur. J. Lipid Sci. Technol. 109, 828-855.

Chilliard, Y., Rouel, J., Ferlay, A., Bernard, L., Gaborit, P., Raynal-Ljutovac, K., Lauret, A., Leroux, C., 2006. Optimising goat's milk and cheese fatty acid composition, in: Williams, C., Buttriss, J. (Eds.), Improving the Fat Content of Foods. Woodhead Publishing Limited, Cambridge, UK, pp. 281-312.

Dallaire, M.P., Taga, H., Ma, L., Corl, B.A., Gervais, R., Lebeuf, Y., Richard, F.J., Chouinard, P.Y., 2014. Effects of abomasal infusion of conjugated linoleic acids, Sterculia foetida oil, and fish oil on production performance and the extent of fatty acid $\Delta^{9}$-desaturation in dairy cows. J. Dairy Sci. 97, 6411-6425.

Enjalbert, F., Nicot, M.C., Bayourthe, C., Moncoulon, R., 1998. Duodenal infusions of palmitic, stearic or oleic acids differently affect mammary gland metabolism of fatty 
acids in lactating dairy cows. J. Nutr. 128, 1525-1532.

Frutos, P., Toral, P.G., Ramos-Morales, E., Shingfield, K.J., Belenguer, A., Hervás, G., 2014. Oral administration of cobalt acetate alters milk fatty acid composition, consistent with an inhibition of stearoyl-coenzyme A desaturase in lactating ewes. J. Dairy Sci. 97, 1036-1046.

Gama, M.A.S., Garnsworthy, P.C., Griinari, J.M., Leme, P.R., Rodrigues, P.H.M., Souza, L.W., Lanna, D.P., 2008. Diet-induced milk fat depression: Association with changes in milk fatty acid composition and fluidity of milk fat. Livest. Sci. 115, 319-331.

Griinari, J.M., Corl, B.A., Lacy, S.H., Chouinard, P.Y., Nurmela, K.V.V., Bauman, D.E., 2000. Conjugated linoleic acid is synthesized endogenously in lactating dairy cows by $\Delta^{9}$-desaturase. J. Nutr. 130, 2285-2291.

Halmemies-Beauchet-Filleau, A., Kokkonen, T., Lampi, A.M., Toivonen, V., Shingfield, K.J., Vanhatalo, A., 2011. Effect of plant oils and camelina expeller on milk fatty acid composition in lactating cows fed diets based on red clover silage. J. Dairy Sci. 94, 4413-4430.

Jenkins, T.C., AbuGhazaleh, A.A., Freeman, S., Thies, E.J., 2006. The production of 10hydroxystearic and 10-ketostearic acids is an alternative route of oleic acid transformation by the ruminal microbiota in cattle. J. Nutr. 136, 926-931.

Jones, E.L., Shingfield, K.J., Kohen, C., Jones, A.K., Lupoli, B., Grandison, A.S., Beever, D.E., Williams, C.M., Calder, P.C., Yaqoob, P., 2005. Chemical, physical, and sensory properties of dairy products enriched with conjugated linoleic acid. J. Dairy Sci. 88, 2923-2937.

Kadegowda, A.K.G., Bionaz, M., Piperova, L.S., Erdman, R.A., Loor, J.J., 2009. Peroxisome proliferator-activated receptor-gamma activation and long-chain fatty acids alter lipogenic gene networks in bovine mammary epithelial cells to various 
extents. J. Dairy Sci. 92, 4276-4289.

Kairenius, P., Ärölä, A., Leskinen, H., Toivonen, V., Ahvenjärvi, S., Vanhatalo, A., Huhtanen, P., Hurme, T., Griinari, J.M., Shingfield, K.J., 2015. Dietary fish oil supplements depress milk fat yield and alter milk fatty acid composition in lactating cows fed grass silage based diets. J. Dairy Sci. 98, 5653-5672.

Leskinen, H., Viitala, S., Mutikainen, M., Kairenius, P., Tapio, I., Taponen, J., Bernard, L., Vilkki, J., Shingfield, K.J., 2016. Ruminal infusions of cobalt EDTA modify milk fatty acid composition via decreases in fatty acid desaturation and altered gene expression in the mammary gland of lactating cows. J. Nutr. 146, 976-985.

Loften, J.R., Linn, J.G., Drackley, J.K., Jenkins, T.C., Soderholm, C.G., Kertz, A.F., 2014. Invited review: Palmitic and stearic acid metabolism in lactating dairy cows. J. Dairy Sci. 97, 4661-4674.

Loor, J.J., Doreau, M., Chardigny, J.M., Ollier, A., Sebedio, J.L., Chilliard, Y., 2005. Effects of ruminal or duodenal supply of fish oil on milk fat secretion and profiles of trans-fatty acids and conjugated linoleic acid isomers in dairy cows fed maize silage. Anim. Feed Sci. Technol. 119, 227-246.

Palmquist, D.L., Lock, A.L., Shingfield, K.J., Bauman, D.E., 2005. Biosynthesis of conjugated linoleic acid in ruminants and humans, in: Taylor, S.L. (Ed.), Advances in Food and Nutrition Research. Vol. 50. Elsevier Academic Press, San Diego, CA, USA, pp. 179-217.

Ramos, M., Juárez, M., 2011. Sheep milk, in: Fuquay, F.W. (Ed.), Encyclopedia of Dairy Sciences. 2nd Edition. Academic Press, San Diego, CA, USA, pp. 494-502.

Raphael, W., Halbert, L., Contreras, G.A., Sordillo, L.M., 2014. Association between polyunsaturated fatty acid-derived oxylipid biosynthesis and leukocyte inflammatory marker expression in periparturient dairy cows. J. Dairy Sci. 97, 3615-3625. 
Rego, O.A., Rosa, H.J.D, Portugal, P., Cordeiro, R., Borba, A.E.S., Vouzela, C.M., Bessa, R.J.B., 2005. Influence of dietary fish oil on conjugated linoleic acid, omega-3 and other fatty acids in milk fat from grazing dairy cows. Livest. Prod. Sci. 95, 27-33.

Reynolds, C.K., Cannon, V.L., Loerch, S.C., 2006. Effects of forage source and supplementation with soybean and marine algal oil on milk fatty acid composition of ewes. Anim. Feed Sci. Technol. 131, 333-357.

Shingfield, K.J., Ahvenjärvi, S., Toivonen, V., Äröla, A., Nurmela, K.V.V., Huhtanen, P., Griinari, J.M., 2003. Effect of dietary fish oil on biohydrogenation of fatty acids and milk fatty acid content in cows. Anim. Sci. 77, 165-179.

Shingfield, K.J., Griinari, J.M., 2007. Role of biohydrogenation intermediates in milk fat depression. Eur. J. Lipid Sci. Technol. 109, 799-816.

Suárez-Vega, A., Toral, P.G., Gutiérrez-Gil, B., Hervás, G., Arranz, J.J., Frutos, P., 2017. Elucidating fish oil-induced milk fat depression in dairy sheep: Milk somatic cell transcriptome analysis. Sci. Rep. 7, 45905.

Timmen, H., Patton, S., 1988. Milk fat globules: Fatty acid composition, size and in vivo regulation of fat liquidity. Lipids 23, 685-689.

Toral, P.G., Bernard, L., Chilliard, Y., Glasser, F., 2013. Short communication: Dietinduced variations in milk fatty acid composition have minor effects on the estimated melting point of milk fat in cows, goats, and ewes: Insights from a meta-analysis. J. Dairy Sci. 96, 1232-1236.

Toral, P.G., Frutos, P., Carreño, D., Hervás, G., 2017. Endogenous synthesis of milk oleic acid in dairy ewes: In vivo measurement using ${ }^{13} \mathrm{C}$-labeled stearic acid. J. Dairy Sci. $100,5880-5887$.

Toral, P.G., Hervás, G., Carreño, D., Frutos, P., 2016. Does supplemental 18:0 alleviate fish oil-induced milk fat depression in dairy ewes? J. Dairy Sci. 99, 1133-1144. 
Toral, P.G., Hervás, G., Carreño, D., Belenguer, A., Frutos, P., 2015. Comparison of milk fatty acid responses during fish oil- and trans-10 cis-12 18:2-induced milk fat depression in dairy ewes. Anim. Feed Sci. Technol. 210, 66-73.

Toral, P.G., Hervás, G., Gómez-Cortés, P., Frutos, P., Juárez, M., de la Fuente, M.A., 2010. Milk fatty acid profile and dairy sheep performance in response to diet supplementation with sunflower oil plus incremental levels of marine algae. J. Dairy Sci. 93, 1655-1667.

Tsiplakou, E., Zervas, G., 2013. Changes in milk and plasma fatty acid profile in response to fish and soybean oil supplementation in dairy sheep. J. Dairy Res. 80, 205-213. 
Table 1

Ingredients and chemical composition of the experimental diets.

\begin{tabular}{|c|c|c|c|c|}
\hline & \multicolumn{4}{|c|}{$\mathrm{TMR}^{\mathrm{A}}$} \\
\hline & Control & FO & FOSA3 & FOSA4 \\
\hline \multicolumn{5}{|l|}{ Ingredients, $\mathrm{g} / \mathrm{kg}$ of fresh matter $^{\mathrm{B}}$} \\
\hline Dehydrated alfalfa hay & 400 & 393 & 383 & 379 \\
\hline Whole maize grain & 180 & 177 & 172 & 171 \\
\hline Whole barley grain & 130 & 128 & 124 & 123 \\
\hline Soybean meal solvent $440 \mathrm{~g} \mathrm{CP} / \mathrm{kg}$ & 150 & 147 & 143 & 142 \\
\hline Sugar beet pulp, pellets & 70 & 69 & 67 & 66 \\
\hline Molasses, liquid & 50 & 49 & 48 & 47 \\
\hline Fish oil & 0 & 17 & 17 & 17 \\
\hline Stearic acid & 0 & 0 & 26 & 34 \\
\hline Mineral and vitamin supplement & 20 & 20 & 20 & 20 \\
\hline \multicolumn{5}{|l|}{ Chemical composition, g/kg DM } \\
\hline Organic matter & 907 & 905 & 912 & 906 \\
\hline Crude protein & 179 & 173 & 172 & 169 \\
\hline Neutral detergent fibre & 259 & 261 & 245 & 255 \\
\hline Acid detergent fibre & 168 & 167 & 151 & 162 \\
\hline $14: 0$ & 0.25 & 0.88 & 0.89 & 0.87 \\
\hline $16: 0$ & 3.87 & 7.47 & 7.58 & 7.64 \\
\hline cis-9 16:1 & 0.05 & 0.85 & 0.85 & 0.83 \\
\hline $18: 0$ & 0.88 & 1.94 & 31.35 & 41.16 \\
\hline cis-9 18:1 & 2.44 & 5.48 & 5.55 & 5.59 \\
\hline cis-11 18:1 & 0.19 & 0.77 & 0.78 & 0.77 \\
\hline $18: 2 n-6$ & 7.43 & 7.69 & 7.54 & 7.56 \\
\hline $18: 3 n-3$ & 2.22 & 2.34 & 2.29 & 2.26 \\
\hline $20: 5 n-3$ & 0.00 & 1.14 & 1.11 & 1.15 \\
\hline $22: 5 n-3$ & 0.00 & 0.29 & 0.28 & 0.29 \\
\hline $22: 6 n-3$ & 0.00 & 4.06 & 4.10 & 4.00 \\
\hline Total fatty acids & 18.23 & 37.23 & 66.63 & 76.43 \\
\hline
\end{tabular}

DM of fish oil alone (FO) or in combination with 3\% (FOSA3) or 4\% (FOSA4) DM of $18: 0 . n=3$.

${ }^{B}$ Details of fish oil, stearic acid, and mineral and vitamin supplements are provided in Toral et al. (2016). 


\section{Table 2}

Milk yield and composition in ewes fed the total mixed ration without lipid supplementation (control) or supplemented with $2 \%$ DM of fish oil alone (FO) or in combination with 3\% (FOSA3) or 4\% (FOSA4) DM of 18:0.

\begin{tabular}{|c|c|c|c|c|c|c|c|c|}
\hline & \multicolumn{4}{|c|}{ Treatment } & \multirow[b]{2}{*}{$\mathrm{SED}^{\mathrm{A}}$} & \multicolumn{3}{|c|}{ Contrast $^{\mathrm{B}}$} \\
\hline & Control & $\mathrm{FO}$ & FOSA3 & FOSA4 & & $\begin{array}{l}\text { Control vs. } \\
\text { FO-diets }\end{array}$ & $\begin{array}{c}\text { FO vs. } \\
\text { FOSA-diets }\end{array}$ & $\begin{array}{c}\text { FOSA3 vs. } \\
\text { FOSA4 }\end{array}$ \\
\hline \multicolumn{9}{|l|}{ Yield, g/d } \\
\hline Milk & 2133 & 2559 & 2307 & 2548 & 354.9 & 0.266 & 0.676 & 0.509 \\
\hline Fat & 126.6 & 121.4 & 109.6 & 109.7 & 12.39 & 0.221 & 0.295 & 0.989 \\
\hline Protein & 114.1 & 125.4 & 116.5 & 119.5 & 11.68 & 0.519 & 0.474 & 0.802 \\
\hline Lactose & 105.4 & 127.1 & 111.7 & 126.1 & 17.34 & 0.275 & 0.598 & 0.422 \\
\hline Total solids & 365.0 & 395.2 & 357.0 & 376.7 & 42.65 & 0.751 & 0.459 & 0.652 \\
\hline \multicolumn{9}{|c|}{ Composition, $\mathrm{g} / \mathrm{kg}$} \\
\hline Fat & 59.9 & 48.4 & 47.9 & 43.5 & 4.04 & 0.002 & 0.453 & 0.295 \\
\hline Protein & 54.3 & 50.3 & 50.6 & 47.7 & 4.32 & 0.197 & 0.764 & 0.515 \\
\hline Lactose & 49.5 & 49.6 & 48.5 & 49.6 & 0.79 & 0.659 & 0.437 & 0.208 \\
\hline Total solids & 172.4 & 156.5 & 155.3 & 149.0 & 7.63 & 0.011 & 0.524 & 0.427 \\
\hline
\end{tabular}

${ }^{\mathrm{A}} \mathrm{SED}=$ standard error of the difference for treatment effects.

${ }^{\text {B }}$ Probability of the contrast. FO diets = diets containing fish oil (i.e., FO, FOSA3 and FOSA4); FOSA diets = diets containing both fish oil and 18:0 (i.e., FOSA3 and FOSA4). 


\section{Table 3}

Milk fatty acid (FA) composition, molar proportions and estimated milk fat melting point in ewes fed the total mixed ration without lipid supplementation (control) or supplemented with 2\% DM of fish oil alone (FO) or in combination with 3\% (FOSA3) or 4\% (FOSA4) DM of 18:0.

\begin{tabular}{|c|c|c|c|c|c|c|c|c|}
\hline \multirow[b]{2}{*}{$\mathrm{FA}, \mathrm{g} / 100 \mathrm{~g}$ total FA } & \multicolumn{4}{|c|}{ Treatment } & \multirow[b]{2}{*}{ SED $^{A}$} & \multicolumn{3}{|c|}{ Contrast $^{\mathrm{B}}$} \\
\hline & Control & $\mathrm{FO}$ & FOSA3 & FOSA4 & & $\begin{array}{c}\text { Control vs. } \\
\text { FO-diets }\end{array}$ & $\begin{array}{c}\text { FO vs. } \\
\text { FOSA-diets }\end{array}$ & $\begin{array}{c}\text { FOSA3 vs. } \\
\text { FOSA4 }\end{array}$ \\
\hline $4: 0$ & 3.12 & 3.07 & 3.35 & 3.49 & 0.283 & 0.429 & 0.181 & 0.635 \\
\hline $6: 0$ & 2.71 & 3.15 & 3.09 & 3.06 & 0.186 & 0.024 & 0.670 & 0.864 \\
\hline $8: 0$ & 2.84 & 3.44 & 3.25 & 3.07 & 0.279 & 0.094 & 0.266 & 0.524 \\
\hline $10: 0$ & 10.27 & 10.72 & 9.31 & 8.49 & 0.798 & 0.268 & 0.022 & 0.322 \\
\hline cis-9 10:1 & 0.28 & 0.32 & 0.27 & 0.26 & 0.029 & 0.866 & 0.041 & 0.769 \\
\hline $12: 0$ & 6.43 & 6.19 & 5.30 & 4.79 & 0.653 & 0.083 & 0.066 & 0.446 \\
\hline cis-9 12:1 & 0.12 & 0.11 & 0.07 & 0.06 & 0.025 & 0.070 & 0.073 & 0.776 \\
\hline $14: 0$ & 12.82 & 12.25 & 11.98 & 10.95 & 0.870 & 0.149 & 0.315 & 0.260 \\
\hline cis-9 14:1 & 0.19 & 0.22 & 0.19 & 0.18 & 0.056 & 0.968 & 0.499 & 0.966 \\
\hline $15: 0$ & 1.11 & 0.87 & 0.85 & 0.80 & 0.057 & $<0.001$ & 0.348 & 0.371 \\
\hline $15: 0$ iso & 0.22 & 0.19 & 0.18 & 0.17 & 0.024 & 0.042 & 0.512 & 0.699 \\
\hline 15:0 anteiso & 0.58 & 0.36 & 0.38 & 0.45 & 0.039 & $<0.001$ & 0.137 & 0.137 \\
\hline $16: 0$ & 25.69 & 25.29 & 21.86 & 21.44 & 1.762 & 0.073 & 0.035 & 0.817 \\
\hline $16: 0$ iso & 0.31 & 0.19 & 0.24 & 0.32 & 0.063 & 0.239 & 0.145 & 0.230 \\
\hline cis-9 16:1 & 0.71 & 1.14 & 1.07 & 1.12 & 0.100 & $<0.001$ & 0.642 & 0.631 \\
\hline trans $-6+7$ 16:1 & 0.06 & 0.16 & 0.16 & 0.16 & 0.014 & $<0.001$ & 0.934 & 0.865 \\
\hline trans-8 16:1 & 0.01 & 0.12 & 0.16 & 0.17 & 0.034 & $<0.001$ & 0.140 & 0.738 \\
\hline trans-9 16:1 & 0.07 & 0.32 & 0.27 & 0.19 & 0.055 & 0.001 & 0.082 & 0.189 \\
\hline $17: 0$ & 0.62 & 0.57 & 0.53 & 0.55 & 0.039 & 0.039 & 0.345 & 0.622 \\
\hline
\end{tabular}




\begin{tabular}{|c|c|c|c|c|c|c|c|c|}
\hline 17:0 iso & 0.33 & 0.40 & 0.38 & 0.39 & 0.025 & 0.010 & 0.401 & 0.538 \\
\hline 17:0 anteiso & 0.56 & 0.35 & 0.41 & 0.47 & 0.049 & 0.002 & 0.075 & 0.252 \\
\hline $18: 0$ & 7.18 & 1.36 & 4.23 & 5.42 & 0.456 & $<0.001$ & $<0.001$ & 0.023 \\
\hline 10-охо-18:0 & 0.01 & 0.39 & 0.40 & 0.44 & 0.073 & $<0.001$ & 0.621 & 0.599 \\
\hline cis-9 18:1 & 12.53 & 5.91 & 9.50 & 11.28 & 0.633 & $<0.001$ & $<0.001$ & 0.016 \\
\hline$c i s-11$ 18:1 & 0.47 & 0.81 & 0.83 & 0.84 & 0.057 & $<0.001$ & 0.587 & 0.905 \\
\hline cis-12 18:1 & 0.26 & 0.27 & 0.07 & 0.07 & 0.130 & 0.251 & 0.091 & 0.991 \\
\hline cis-13 18:1 & 0.05 & 0.07 & 0.06 & 0.07 & 0.007 & 0.006 & 0.136 & 0.766 \\
\hline$\sum$ cis $18: 1$ & 13.43 & 7.19 & 10.58 & 12.38 & 0.610 & $<0.001$ & $<0.001$ & 0.012 \\
\hline trans $-6+7+8 \quad 18: 1$ & 0.21 & 0.21 & 0.15 & 0.13 & 0.050 & 0.321 & 0.126 & 0.719 \\
\hline trans-9 18:1 & 0.19 & 0.44 & 0.33 & 0.31 & 0.070 & 0.012 & 0.077 & 0.719 \\
\hline trans-10 18:1 & 0.36 & 3.12 & 4.63 & 5.48 & 1.109 & $<0.001$ & 0.068 & 0.457 \\
\hline trans-11 18:1 & 0.84 & 3.78 & 2.89 & 1.96 & 0.712 & 0.004 & 0.049 & 0.214 \\
\hline trans-12 18:1 & 0.27 & 0.51 & 0.37 & 0.34 & 0.074 & 0.050 & 0.037 & 0.712 \\
\hline trans-13+14 18:1 & 0.29 & 0.42 & 0.29 & 0.23 & 0.079 & 0.716 & 0.036 & 0.457 \\
\hline trans-15 18:1 & 0.20 & 0.18 & 0.14 & 0.14 & 0.024 & 0.058 & 0.054 & 0.771 \\
\hline trans-16+cis-14 18:1 & 0.29 & 0.13 & 0.08 & 0.07 & 0.022 & $<0.001$ & 0.016 & 0.803 \\
\hline$\sum$ trans $18: 1$ & 2.39 & 8.70 & 8.83 & 8.61 & 0.516 & $<0.001$ & 0.963 & 0.684 \\
\hline trans-9 trans-12-18:2 & 0.01 & 0.07 & 0.10 & 0.11 & 0.014 & $<0.001$ & 0.036 & 0.488 \\
\hline cis-9 trans-12-18:2 & 0.04 & 0.08 & 0.06 & 0.06 & 0.009 & 0.001 & 0.048 & 0.980 \\
\hline trans -9 cis $-12-18: 2$ & 0.03 & 0.11 & 0.10 & 0.09 & 0.014 & $<0.001$ & 0.400 & 0.608 \\
\hline trans -11 cis $-15+$ trans -10 cis-15 18:2 & 0.04 & 0.44 & 0.53 & 0.49 & 0.054 & $<0.001$ & 0.120 & 0.487 \\
\hline cis-9 cis-12-18:2 & 2.58 & 1.75 & 1.93 & 1.97 & 0.209 & 0.001 & 0.298 & 0.849 \\
\hline$\sum$ non-conjugated 18:2 & 3.24 & 3.00 & 3.13 & 3.15 & 0.211 & 0.425 & 0.452 & 0.904 \\
\hline cis-9 trans-11 CLA ${ }^{\mathrm{C}}$ & 0.47 & 1.88 & 1.32 & 1.02 & 0.346 & 0.006 & 0.036 & 0.401 \\
\hline trans-9 cis-11 CLA & 0.02 & 0.07 & 0.08 & 0.10 & 0.015 & $<0.001$ & 0.270 & 0.400 \\
\hline trans-10 cis-12 CLA & 0.006 & 0.006 & 0.010 & 0.010 & 0.0018 & 0.164 & 0.022 & 0.768 \\
\hline$\sum$ CLA & 0.56 & 2.02 & 1.48 & 1.19 & 0.332 & 0.003 & 0.035 & 0.400 \\
\hline
\end{tabular}




\begin{tabular}{|c|c|c|c|c|c|c|c|c|}
\hline $18: 3 n-3$ & 0.55 & 0.45 & 0.46 & 0.47 & 0.052 & 0.061 & 0.740 & 0.764 \\
\hline $20: 0$ & 0.18 & 0.15 & 0.19 & 0.21 & 0.017 & 0.812 & 0.004 & 0.394 \\
\hline$c i s-1120: 1$ & $<0.01$ & 0.25 & 0.26 & 0.27 & 0.017 & $<0.001$ & 0.482 & 0.502 \\
\hline$\sum 20: 1$ & 0.06 & 0.43 & 0.43 & 0.44 & 0.024 & $<0.001$ & 0.933 & 0.822 \\
\hline $20: 4 n-6$ & 0.20 & 0.21 & 0.23 & 0.22 & 0.019 & 0.227 & 0.526 & 0.743 \\
\hline $20: 5 n-3$ & 0.05 & 0.37 & 0.42 & 0.42 & 0.043 & $<0.001$ & 0.188 & 0.843 \\
\hline$\sum$ unsaturated C20 & 0.43 & 1.45 & 1.50 & 1.47 & 0.104 & $<0.001$ & 0.721 & 0.770 \\
\hline $22: 0$ & 0.09 & 0.08 & 0.08 & 0.08 & 0.014 & 0.477 & 0.869 & 0.604 \\
\hline$\sum 22: 1$ & 0.03 & 0.34 & 0.34 & 0.38 & 0.034 & $<0.001$ & 0.404 & 0.333 \\
\hline $22: 5 n-6$ & 0.01 & 0.14 & 0.14 & 0.13 & 0.014 & $<0.001$ & 0.819 & 0.841 \\
\hline $22: 5 n-3$ & 0.09 & 0.39 & 0.44 & 0.47 & 0.054 & $<0.001$ & 0.178 & 0.590 \\
\hline $22: 6 n-3$ & 0.03 & 1.10 & 1.32 & 1.37 & 0.156 & $<0.001$ & 0.089 & 0.735 \\
\hline$\sum$ unsaturated $\mathrm{C} 22$ & 0.24 & 2.75 & 3.01 & 3.24 & 0.310 & $<0.001$ & 0.191 & 0.466 \\
\hline$\sum$ saturated FA & 75.96 & 70.08 & 67.02 & 65.60 & 0.964 & $<0.001$ & $<0.001$ & 0.166 \\
\hline$\sum$ monounsaturated FA & 18.77 & 20.36 & 23.56 & 25.07 & 0.815 & $<0.001$ & $<0.001$ & 0.089 \\
\hline$\sum$ polyunsaturated FA & 5.20 & 9.34 & 9.22 & 9.12 & 0.541 & $<0.001$ & 0.725 & 0.865 \\
\hline$\sum$ odd- and branched-chain FA & 4.95 & 4.22 & 4.22 & 4.44 & 0.169 & $<0.001$ & 0.482 & 0.225 \\
\hline$\sum<\mathrm{C} 16 \mathrm{FA}$ & 41.50 & 41.63 & 38.91 & 36.44 & 1.800 & 0.114 & 0.026 & 0.195 \\
\hline$\sum \mathrm{C} 16 \mathrm{FA}$ & 27.45 & 27.94 & 24.43 & 24.02 & 1.806 & 0.203 & 0.035 & 0.825 \\
\hline$\sum>\mathrm{C} 16 \mathrm{FA}$ & 30.99 & 30.29 & 36.52 & 39.40 & 1.301 & 0.001 & $<0.001$ & 0.047 \\
\hline Estimated milk fat melting point $\left({ }^{\circ} \mathrm{C}\right)$ & 36.06 & 34.14 & 33.27 & 32.99 & 0.669 & $<0.001$ & 0.107 & 0.684 \\
\hline
\end{tabular}

${ }^{\text {A }} \mathrm{SED}=$ standard error of the difference for treatment effects.

${ }^{\mathrm{B}}$ Probability of the contrast. FO diets = diets containing fish oil (i.e., FO, FOSA3 and FOSA4); FOSA diets = diets containing both fish oil and 18:0 (i.e., FOSA3 and FOSA4).

${ }^{\mathrm{C}}$ Contains trans- 7 cis-9 and trans-8 cis-10 conjugated linoleic acids (CLA) as minor components. 